\title{
Sexually transmitted diseases among randomly selected attenders at an antenatal clinic in The Gambia
}

\author{
D C W MABEY,* N E LLOYD-EVANS, $+\mathrm{S}$ CONTEH, + AND T FORSEY \\ From the *MRC Laboratories, the †Joint Gambia Government/MRC Research Unit, MRC Laboratories, \\ Fajara, The Gambia, West Africa, and the $¥$ Subdepartment of Virology, Institute of Ophthalmology, \\ London
}

SUMMARY One hundred randomly selected women attending a free government antenatal clinic in the town of Bakau, The Gambia, were examined. Vaginal swabs were taken for microscopical examination for Trichomonas vaginalis and for culture on Sabouraud's medium. Cervical swabs were taken for culture of Neisseria gonorrhoeae and Chlamydia trachomatis and, in 50 cases, Herpesvirus hominis; in addition, urethral swabs were taken for culture of $N$ gonorrhoeae. Serum samples were tested for antibodies to Treponema pallidum by the Venereal Diseases Research Laboratory (VDRL) test and $T$ pallidum haemagglutination assay (TPHA), and to $C$ trachomatis and $H$ hominis by microimmunofluorescence. The prevalence of infection with Candida albicans was found to be $35 \%, T$ vaginalis $32 \%, C$ trachomatis $6 \cdot 9 \%, N$ gonorrhoeae $6 \cdot 7 \%, T$ pallidum $1 \%$, and $H$ hominis $0 \%$. IgG antibodies at a titre of at least $1 / 16$ to $C$ trachomatis serotypes D-K were found in $29.4 \%$, and to serotypes A-C in a further $10.6 \%$. IgG antibodies at a titre of at least $1 / 16$ to $H$ hominis type I were found in $94 \%$, and to type II in $53 \%$, although a proportion of the latter probably represent cross reacting antibodies to type I.

\section{Introduction}

Those who have worked in the specialty generally agree that sexually transmitted diseases (STD) are a major problem in developing countries. ${ }^{1-3}$ As they are not notifiable in most of these countries, however, and as STD clinics are few and far between, the exact extent of the problem remains unknown. In a few African countries an attempt has been made to calculate the incidence of gonorrhoea by dividing the number of patients seen in a hospital in a given period by the population that it is thought to serve. ${ }^{45}$ In this way the yearly incidence of gonorrhoea in Swaziland and in Uganda has been estimated to be between 3000 and 10000 per 100000 total population, though clearly this method may underestimate the true incidence. An ingenious attempt has been made to calculate the incidence of syphilis in Swaziland from the rate at which positive results to serology tests increased with age, ${ }^{6}$ but in many African countries this is not possible because ages of

Address for reprints: Dr D C W Mabey, MRC Laboratories, Fajara, The Gambia, West Africa

Accepted for publication 6 January 1984 patients are not accurately known; moreover, positive results to serology tests in older patients may be due to endemic treponematoses rather than venereal syphilis.

An alternative method of estimating the importance of STD in a community is to measure its prevalence in a representative sample of the population. The problem here lies in the selection of the sample to be studied. Apart from the work of Arya et al in rural Uganda, ${ }^{7}$ most prevalence studies so far reported from Africa have been based on patients attending either family planning or antenatal clinics in urban areas. ${ }^{8-12}$ How representative these are of the general population depends on the proportion of the population which attends the clinic, and how this proportion is selected. This is difficult to ascertain and varies according to the cost of treatment at each clinic as well as its location and reputation, which may account for some of the widely divergent results that have been reported by different authors.

In The Gambia free antenatal care is provided by the government, and it is estimated that at least $\mathbf{9 0 \%}$ of pregnant women living in the town of Bakau, in which this study was carried out, attend the clinic on at least one occasion in each pregnancy (MGM 
Rowland, unpublished observation). We undertook this study to discover the prevalence of a variety of STDs among antenatal clinic attenders in this community.

\section{Patients and methods}

The Gambia is a small country on the west coast of Africa between latitudes $13^{\circ}$ and $14^{\circ} \mathrm{N}$. The population (between half a million and one million) is heterogeneous, consisting of four major tribes and several smaller minorities. The people are mainly Moslems, apart from the Jola tribe (most of whom are Roman Catholics) and the westernised professional classes in the capital (who are mainly Christians of various denominations). Polygamy is practised, and bride prices are high in relation to average earnings. Women are not strictly confined as in some Moslem countries, however, and many enjoy a considerable degree of independence.

This study was carried out between November 1981 and February 1982 on randomly selected patients in the third trimester of pregnancy attending the antenatal clinic in the town of Bakau (population 10 000), which is eight miles from the capital, Banjul. Every tenth patient was examined until 100 had been seen; only one of those asked to participate in the study declined to do so. The age, tribal origin, and obstetric history of each patient were recorded and they were specifically asked about the presence of lower abdominal pains, vaginal discharge, and pain on passing urine. A vaginal speculum was passed and the following specimens were taken: (1) a swab from the posterior fornix (examined for Trichomonas vaginalis in a wet preparation); (2) a swab from the posterior fornix or any other site where discharge had collected (cultured for Candida albicans on Sabouraud's medium); (3) cervical and urethral swabs for the isolation of Neisseria gonorrhoeae (plated direct on to modified Thayer-Martin medium and transferred to a 5\% carbon dioxide incubator jar within two hours); (4) an endocervical swab for isolation of Chlamydia trachomatis (expressed immediately into sucrose phosphate transport medium containing $10 \%$ fetal calf serum and stored at $-70^{\circ} \mathrm{C}$ ); (5) an additional endocervical swab was taken from 50 patients for the isolation of Herpesvirus hominis (expressed immediately into viral transport medium containing $10 \%$ fetal calf serum and stored at $-70^{\circ} \mathrm{C}$ ); and (6) from all patients, $3 \mathrm{ml}$ of venous blood (separated the same day; serum was stored at $-20^{\circ} \mathrm{C}$ ).

IDENTIFICATION OF PATHOGENS

The swabs were tested as follows:

Candida albicans - Inoculated plates of Sabouraud's medium were incubated at $37^{\circ} \mathrm{C}$ for 48 hours, and colonies were examined as a wet preparation; yeasts were identified as $C$ albicans by the germ tube test.

Neisseria gonorrhoeae-After incubation at $37^{\circ} \mathrm{C}$ in $5 \%$ carbon dioxide for 48 hours, isolates were confirmed as $N$ gonorrhoeae by colonial appearance, Gram stain, and oxidase test.

Chlamydia trachomatis-Specimens were inoculated by centrifugation $\left(2500 \times g\right.$ at $33^{\circ} \mathrm{C}$ for 1 hour) on to McCoy cells, which were subsequently treated with cycloheximide $2 \mathrm{mg} / \mathrm{l}$ in minimum essential medium containing glucose and $10 \%$ fetal calf serum, as described by Ripa and Mårdh. ${ }^{13}$ Monolayers were stained with Giemsa at 48 hours and examined for inclusions by dark field microsocopy.

Herpesvirus hominis-Specimens were inoculated on to Vero cells in minimum essential medium with $5 \%$ fetal calf serum and examined daily for five days for cytopathic effect. A final examination was made after 14 days before specimens were discarded as negative.

SEROLOGICAL ANALYSIS

Serum samples were analysed as follows: the Venereal Diseases Research Laboratory (VDRL) test was performed according to standard techniques using undiluted serum and Wellcome reagent VD02-03; the Treponema pallidum haemagglutination assay (TPHA) was performed according to standard techniques using serum at dilutions of $1 / 80$ and 1/160 with reagent obtained from Fujizoki pharmaceutical company, Tokyo; and tests for antibody to $C$ trachomatis and Herpesvirus hominis were carried out at the Institute of Ophthalmology, London.

Serum was examined for type specific antibodies at starting dilutions of $1 / 16$ for IgG and $1 / 8$ for IgM. A modified microimmunofluorescence test, ${ }^{14}$ using pooled, egg grown preparations of $C$ trachomatis serotypes A-C (trachoma types), D-K (oculogenital types), LGV 1 to LGV 3 (lymphogranuloma venereum types), and of $C$ psittaci was used to detect antibodies to chlamydiae. Antibodies to herpes virus were detected by a microimmunofluorescence test ${ }^{15}$ using cell culture grown antigens of herpes simplex types I and II.

TABLE I Tribal origins of 100 antenatal patients

\begin{tabular}{lc}
\hline Tribe & No \\
\hline Jola & 44 \\
Mandinka & 21 \\
Wollof & 11 \\
Fula & 13 \\
Other & 11 \\
\hline
\end{tabular}




\section{Results}

\section{CLINICAL FINDINGS}

Table I shows the tribal origins of the 100 women examined (average age 23-6 (range 16-40) years).

Table II shows the symptoms described by these women on direct questioning. An abnormal vaginal discharge was noted on examination in 67, only 24 of whom had complained of this. There were 10 patients who complained of discharge in whom no abnormality was noted.

TABLE II Prevalence of symptoms described by 100 antenatal patients on direct questioning

\begin{tabular}{lc}
\hline Symptom & $\%$ \\
\hline Lower abdominal pain & 55 \\
Vaginal discharge & 34 \\
Dysuria & 27 \\
No symptoms & 34 \\
\hline
\end{tabular}

\section{PATHOGENS ISOLATED}

Table III shows the prevalence of the various infective agents in this population. As was expected in view of the small numbers involved, no appreciable association was found between the isolation of $N$ gonorrhoeae or $C$ trachomatis and any symptom or sign; all six patients harbouring $N$ gonorrhoeae and five of the six with $C$ trachomatis had at least one symptom. Dysuria was complained of significantly more frequently in those infected with $C$ albicans $(15$ out of 35 ) than in those not infected (12 out of 65 ) $\left(\chi^{2}=5 \cdot 3, p<0.025\right)$. A vaginal discharge was seen in significantly more of those harbouring $T$ vaginalis (28 out of 32) than in those who were not (39 out of 68) $\left(\chi^{2}=7 \cdot 9, \mathrm{p}<0 \cdot 005\right)$.

TABLE III Isolation of pathogens from 100 antenatal patients

\begin{tabular}{lll}
\hline Pathogen & No tested & No $(\%)$ positive \\
\hline Candida albicans & 100 & $35(35)$ \\
Trichomonas vaginalis & 100 & $32(32)$ \\
Neisseria gonorrhoeae & 90 & $6(6 \cdot 7)$ \\
Chlamydia trachomatis & 87 & $6(6 \cdot 9)$ \\
Herpesvirus hominis & 50 & $0(0)$ \\
\hline
\end{tabular}

NB 10 specimens for isolation of $N$ gonorrhoeae and $C$ trachomatis were lost due to electricity failure; three specimens for isolation of $C$ trachomatis were contaminated.

\section{SEROLOGY}

Table IV shows the results of serological tests. Although the VDRL test was positive in nine cases, the TPHA was only positive in one. The remaining eight are presumably biological false positives due to pregnancy or a disease such as malaria, which is
TABLE IV Prevalence of antibodies to various pathogens in 100 antenatal patients

\begin{tabular}{lllc}
\hline Pathogen & Test used & $\begin{array}{l}\text { No } \\
\text { tested }\end{array}$ & No (\%) postive \\
\hline T pallidum & VDRL & 100 & $9(9)$ \\
T pallidum & TPHA & 100 & $1(1)$ \\
C trachomatis A-C & MIF (IgG) & 85 & $9(10 \cdot 6)$ \\
C trachomatis D-K & MIF (IgG) & 85 & $25(29 \cdot 4)$ \\
H hominis type I & MIF (IgG) & 85 & $80(94 \cdot 1)$ \\
$H$ hominis type II & MIF (IgG) & 85 & $45(52 \cdot 9)^{*}$ \\
\hline
\end{tabular}

VDRL $=$ Venereal Diseases Research Laboratory test; TPHA $=T$ pallidum haemagglutination assay; MIF = Microimmunofluorescence test (a titre of $1 / 16$ or more was considered positive).

*In all but $7 \%$ the titre to $H$ hominis type I was higher than to type II.

NB 15 serum samples were lost in transit between The Gambia and the Institute of Ophthalmology.

prevalent in this area at the season when the study was undertaken.

IgG antibodies to $C$ trachomatis were found at a titre of at least $1 / 16$ in $34(40.0 \%)$ specimens tested. In $25(29 \cdot 4 \%)$ patients, these antibodies were to $C$ trachomatis serotypes D-K. In two of these women (whose swabs had not yielded chlamydia on culture) IgM against these serotypes was also detected at titres of $1 / 8$ and $1 / 16$. Nine $(10 \cdot 6 \%)$ patients had IgG antibodies specific for $C$ trachomatis serotypes A-C. No patient had antibodies specific for lymphogranuloma venereum types of $C$ trachomatis or $C$ psittaci. The figure shows the distribution of titres of IgG antibodies to $C$ trachomatis serotypes D-K among 85 patients tested. Their average age was $24 \cdot 3$ years, which is not appreciably different from the average age of the whole study population ( 23.6 years). Table $\mathrm{V}$ shows the prevalence of antibodies to $C$ trachomatis by tribal group; although it was higher

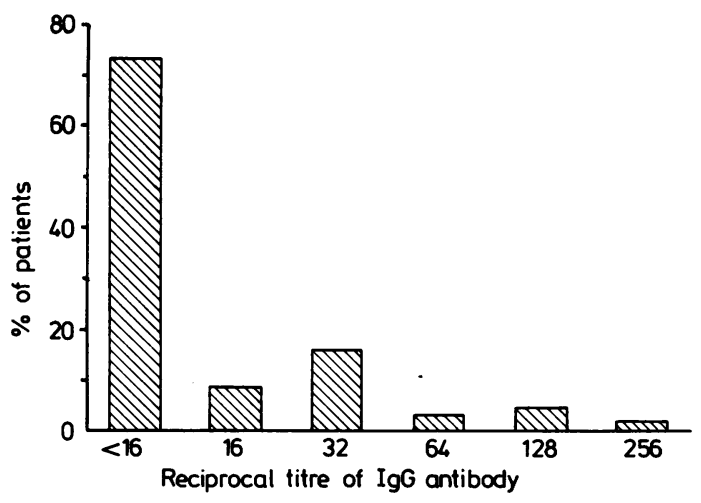

FIGURE Distribution of titres of $\lg G$ antibodies to Chlamydia trachomatis serotypes $D-K$ in 85 antenatal patients. 
TABLE V Chlamydial antibody prevalence by tribe (serotypes $D-K)$

\begin{tabular}{llc}
\hline Tribe & No tested & No (\%) positive \\
\hline Jola & 37 & $14(37 \cdot 8)^{*}$ \\
Mandinka & 19 & $4(21 \cdot 1)$ \\
Fula & 11 & $3(27 \cdot 3)$ \\
Wollof & 11 & $3(27 \cdot 3)$ \\
\hline
\end{tabular}

*Jolas $v$ others: 14 out of $37 v 10$ out of $41\left(\chi^{2}=1.65 ; p>0 \cdot 2\right)$.

among Jola women than others, the difference was not significant. It is, however, remarkable that all six women from whom $C$ trachomatis was isolated belonged to this tribe. Patients yielding positive isolation results tended to be among the younger women examined (average 20.5 (range 18-24) years).

IgG antibodies to $H$ hominis type I were present at a titre of at least 1/16 in $94 \%$ of women tested, and to type II in $52.9 \%$. Many of the latter represent cross reacting type I antibodies, however, as the titre of antibodies to type I was higher in all but $7 \%$. No patient had IgM antibodies to $H$ hominis, and herpes virus was not isolated from any of the 50 women from whom swabs were tested.

\section{Discussion}

The prevalence of infection with $T$ vaginalis $(32 \%)$ found in this study is similar to that reported among randomly selected women in other antenatal clinics in Africa. In Ibadan it was found to be $21 \%,,^{10}$ in Swaziland 23\%, ${ }^{11}$ in Zambia $38 \%,{ }^{16}$ and in Durban $49 \% .{ }^{17}$ By contrast, a study in Britain showed a prevalence of $4 \% .^{18}$ While $17(53 \%)$ of our patients with this infection did not complain of vaginal discharge, there was an appreciable association between infection with $T$ vaginalis and an abnormal discharge seen on examination. Of the 67 women in whom an abnormal discharge was seen, however, 39 (58\%) were not infected with $T$ vaginalis, and 27 of these were not infected with $C$ albicans either. Presumably other pathogens such as Gardnerella vaginalis are also prevalent in this community and were responsible for the vaginal discharge seen in these patients. It is interesting to note that $G$ vaginalis was isolated from 75 of 100 patients complaining of vaginal discharge in Nairobi. ${ }^{19}$

The prevalence of infection with $C$ albicans $(35 \%)$ seen in this community is also similar to that found in random surveys in other African antenatal clinics (23\% in Durban, ${ }^{17} 33 \%$ in Ibadan, ${ }^{10} 37 \%$ in Swaziland $^{\text {"1)}}$. We found that isolation of this organism was associated with dysuria. Apart from the discomfort it may cause mothers, $C$ albicans may infect infants in up to $50 \%$ of cases, ${ }^{20}$ and a high incidence of oral thrush has been seen in neonates in this community (MGM Rowland, unpublished observation.) This is occasionally so severe as to interfere with breast feeding.

The prevalence of gonorrhoea in African antenatal clinics has been found to vary from $0 \%$ in a small study population in Nairobi ${ }^{9}$ to $14 \%$ in Yaoundé. ${ }^{12}$ It was $6.7 \%$ in this study and in most published studies it has been between $3 \%$ and $10 \% .^{101121}$ That the prevalence may be even higher in rural areas is suggested by the findings of Arya et al, who showed $40 \%$ of pregnant women in the Teso district of Uganda to be infected, ${ }^{7}$ and those of Widy-Wirski and D'Costa who found $27.5 \%$ of all women in one rural village in the Central African Republic had gonorrhoea. ${ }^{22}$

Apart from the present study, in which $C$ trachomatis was isolated from $6.9 \%$ of patients, we are aware of only two other attempts to isolate this organism from the cervices of women in Africa. Nsanze et al isolated $C$ trachomatis from three $(6 \%)$ of 54 antenatal patients in Nairobi, ${ }^{9}$ and in Johannesburg, Ballard et al isolated it from 13\% of women attending an STD clinic and $16 \%$ of those attending a family planning clinic. ${ }^{23}$ We found circulating IgM antibody to $C$ trachomatis types $\mathrm{D}-\mathrm{K}$, which is strongly suggestive of active infection, in a further two patients. IgG antibodies to $C$ trachmatis types D-K were found in $\mathbf{2 9 . 4 \%}$ of our patients at a titre of at least $1 / 16$. A further $10.6 \%$ had IgG antibodies to serotypes A-C, which may reflect exposure to genital infection or trachoma. High titres of IgG antibodies to $C$ trachomatis have been found in the sexually active population in Nairobi ${ }^{9}$ and Johannesburg ${ }^{23}$ as well as among STD clinic attenders in Ethiopia. ${ }^{24}$ Among antenatal patients in Ibadan, Nigeria, the prevalence of IgG antibodies to types D-K was $8 \cdot 4 \% .{ }^{25}$ Ballard has suggested that, by analogy with the chronic chlamydial eye disease, trachoma, the likelihood of isolating $C$ trachomatis is reduced in patients with chronic cervical infections and high titres of circulating antibody. This would suggest that the true prevalence of genital $C$ trachomatis infection is higher than isolation figures suggest in communities with a high prevalence of circulating antibody, which is a debatable hypothesis.

Heyman estimated that $30 \%$ of babies born to women with cervical gonorrhoea develop gonococcal ophthalmia neonatorum. ${ }^{26}$ This potentially blinding condition is therefore likely to occur in about $2 \%$ of babies born in Bakau. A previous study showed that $30 \%$ of infants born in the government hospital in Banjul developed conjunctivitis in the first three days of life. ${ }^{27}$ Although most of these cases were neither severe nor of gonococcal origin, it would seem that prophylaxis with silver nitrate may play a useful part 
in preventing serious eye disease in Gambian infants

The role of $C$ trachomatis in the aetiology of ophthalmia neonatorum in Africa has been studied little, and was first described in The Gambia in 1965 by the MRC Trachoma Unit. ${ }^{28}$ We described a series of 37 patients with ophthalmia neonatorum in whom $C$ trachomatis was isolated from $35 \%$ and $N$ gonorrhoeae from $24 \% .{ }^{29}$ Méheus et al found a 9.7\% incidence of ophthalmia neonatorum in Bangui, $26 \%$ of cases being due to $N$ gonorrhoeae and $19 \%$ to $C$ trachomatis. ${ }^{30}$ The incidence of other diseases due to $C$ trachomatis among neonates, such as pneumonitis, is not known and is currently under investigation.

The most important complications of gonorrhoea are pelvic inflammatory disease (PID) and its sequelae, notably ectopic pregnancy and infertility. Weström et al have shown that in Sweden the incidence of ectopic pregnancy is increased sevenfold following an attack of PID. ${ }^{31}$ Figures for the incidence of ectopic pregnancy in Africa are scarce, but several workers have drawn attention to the high incidence of PID in Africa, ${ }^{32}{ }^{33}$ and most have linked it with gonococcal infection. ${ }^{33-35} \mathrm{C}$ trachomatis is the major cause of PID in certain industrialised countries. ${ }^{36}$ The results of this study and those from Nairobi and Johannesburg suggest that $C$ trachomatis may be at least as important as $N$ gonorrhoeae in causing PID in Africa.

At least $12 \%$ of women in Sweden are rendered infertile after a single attack of PID, even with optimum antibiotic treatment, ${ }^{37}$ and the figure rises to over $30 \%$ after two attacks. In Africa, where suitable antibiotic treatment is not obtainable in many areas, it seems likely that a higher proportion of women become infertile following an attack of PID. Many workers have drawn attention to the high rate of infertility in certain parts of Africa. ${ }^{32}$ 38-40 In The Gambia, a careful longitudinal study of births and deaths over 25 years in two rural villages has shown that $3 \%$ to $5 \%$ of women suffer from primary infertility, and $13 \%$ to $19 \%$ from secondary infertility (defined as failure to bear children after the age of 30). ${ }^{41}$ Exact figures are not available for other areas, but over $50 \%$ of gynaecological consultations in the government hospital in Banjul are for infertility, and most women investigated by hysterosalpingography or at operation have bilateral tubal occlusions (G Ogbaselassie, unpublished observation). Ballard et al have shown appreciably higher titres of circulating chlamydial antibody in women in Johannesburg with tubal infertility than in controls with normal fallopian tubes, suggesting that chlamydial salpinigitis is an important cause of infertility in that community. ${ }^{23}$ Similar studies are needed elsewhere in Africa if a rational policy is to be suggested for the control of PID and its sequelae.
It is sometimes stated that venereal syphilis in Africa is more common in urban areas. ${ }^{42-44}$ This has not been our experience in The Gambia. Only one of 100 urban women in this study had serological evidence of syphilis, whereas at a mission hospital 60 miles from the capital 11 of 100 randomly selected antenatal patients had positive results to VDRL and TPHA tests (DCW Mabey, unpublished observation). Endemic treponematosis was prevalent in The Gambia in the early 1950 s, ${ }^{45}$ before the World Health Organisation's yaws eradication programme, but has not been seen here subsequently. It therefore seems likely that all positive serological tests in patients aged under $\mathbf{3 0}$ are due to venereal syphilis.

Congenital syphilis is diagnosed fairly frequently at the government hospital in Banjul and at the MRC hospital in Bakau (about 30 cases a year in all), but many other cases are probably missed as serological tests are not performed elsewhere in the country. Late manifestations of congenital syphilis are rarely seen in The Gambia. For example, only one case of interstitial keratitis has been seen at the government eye clinic in the past eight years (S Sowa, unpublished observation). This suggests either that there is a very high mortality among those with congenital syphilis, or that the disease is becoming more common. If the latter is the case, it may well be that we are experiencing an epidemic of venereal syphilis in a population previously rendered immune by endemic treponematosis in childhood. This hypothesis is supported by the relative rarity of tertiary syphilis.

It is difficult to interpret the results of serological tests for antibody to $H$ hominis, as there is cross reaction between antibodies to types I and II with the microimmunofluorescence test used. ${ }^{15}$ It is clear that at least $90 \%$ of patients studied had IgG antibody to type I. Although antibodies to type II were detected in $53 \%$ of patients, in all but $7 \%$ of them the titre of type I antibodies was higher, suggesting the possibility of cross reacting type I antibodies. Studies of the aetiology of genital ulceration in Africa suggest that $H$ hominis is responsible for a much smaller proportion of ulcers than in Europe and North America..$^{4647}$ In a pilot study carried out in The Gambia in $1981 \mathrm{H}$ hominis was isolated from only one of 37 men with genital ulceration (DCW Mabey and HC Whittle, unpublished observation). This may simply reflect the higher prevalence of genital ulceration due to other pathogens in Africa, although it is tempting to postulate that Africans are protected from genital herpes by antibodies acquired in childhood as a result of non-venereal infections. Neutralising antibodies to $\boldsymbol{H}$ hominis type II have been found in young Nigerian children, ${ }^{48}$ and further studies are needed in other areas to elucidate this issue. 


\section{References}

1. Anonymous Annual medical and sanitary report for 1921 . Entebbe, Uganda: Government Printer, 1921; Appendix III: 69.

2. Arya OP, Osoba AO, Bennett FJ. Tropical Venereology. 1st ed. Edinburgh, London, and New York: Churchill Livingstone, 1980.

3. Osoba AO. Sexually transmitted diseases in tropical Africa: a review of the present situation. Br J Vener Dis 1981;57:89-94.

4. Arya OP. Changing patterns in the organisation of the venereal diseases and treponematoses service in Uganda. $\mathrm{Br} J$ Vener Dis 1973;49: 134-8.

5. Méheus A, Ballard R, Dlamini M, Ursi JP, van Dyck E, Piot $P$. Epidemiology and aetiology of urethritis in Swaziland. Int J Epidemiol 1980;9:239-45.

6. Ursi JP, van Dyck E, van Houtte $C$, et al. Syphilis in Swaziland: a serological study. Br J Vener Dis 1981;57:95-9.

7. Arya OP, Nsanzumuhire $H$, Taber SR. Clinical, cultural and demographic aspects of gonorrhoea in a rural community in Uganda. Bull WHO 1973; 49:587-95.

8. Hopcraft M, Verhagen AR, Ngigi S, Haga ACA. Genital infections in developing countries: experience in a family planning clinic. Bull WHO 1973;48:581-6.

9. Nsanze H, Waigwa SRN, Mirza N, Plummer F, Roelants P, Piot P. Chlamydial infections in selected populations in Kenya. In: Mårdh P-A, et al, eds. Chlamydial infections. Amsterdam: Elsevier Biomedical Press, 1982;421-4.

10. Osoba AO, Onifade A. Venereal diseases among pregnant women in Nigeria. West Afr Med J 1973;22:23-5.

11. Méheus A, Friedman F, van Dyck E, Guyver T. Genital infections in prenatal and family planning attendants in Swaziland. East Afr Med J 1980;57:212-7.

12. Nasah BT, Nguematcha R, Eyong M, Godwin S. Gonorrhoea, trichomonas and candida among gravid and non-gravid women in Cameroon. Int J Gynaecol Obstet 1980; 18:48-52.

13. Ripa KI, Mårdh P-A. New simplified culture techniques for Chlamydia trachomatis. In: Hobson D, Holmes KK, eds. Nongonococcal urethritis and related infections. Washington DC: American Society for Microbiology, 1977;323-7.

14. Treharne JD, Darougar S, Jones BR. Modification of the microimmunofluorescence test to provide a routine serodiagnostic test for chlamydial infection. J Clin Pathol 1977; 30: 510-7.

15. Forsey T, Darougar S. Indirect immunofluorescence test for detecting type-specific antibodies to herpes simplex virus. $J$ Clin Pathol 1980;33:171-6.

16. Hira PR. Observations on Trichomonas vaginalis infections in Zambia. J Hyg Epidemiol Microbiol Immunol (Praha) 1977; 21:215-24.

17. Hoosen AA, Ross SM, Mulla MJ, Patel M. The incidence of selected vaginal infections among pregnant urban blacks. $S A f r$ Med J 1981;59:827-9.

18. Bramley M. Study of female babies of women entering confinement with vaginal trichomoniasis. Br J Vener Dis 1976; 52:58-62.

19. Mirza NB, Nsanze H, D'Costa LJ, Piot P. Microbiology of vaginal discharge in Nairobi, Kenya. Br J Vener Dis 1983;59: 186-8.

20. Kozinn PJ, Taschdjian CL, Wiener $\mathbf{H}$. Incidence and pathogenesis of neonatal candidiasis. Pediatrics 1958;21:421-9.

21. Finlayson MH, Gibbs B, Brede HD. Diagnosis and incidence of Neisseria gonorrhoeae in cape coloured females in the Western Cape. S Afr Med J 1974; 48:259-60.

22. Widy-Wirski R, D'Costa LJ. Maladies transmises par voie sexuelle dans une population rurale en Centrafrique. In: Rapport final, 13th Conference Technique, Yaoundé. OCEAC 1980:651.

23. Ballard RC, Fehler HG, Duncan MO, Van det Wat IJ. Urethritis and associated infections in Johannesburg-the role of Chlamydia trachomatis. Southern African Journal of Sexually Transmitted Diseases 1981;1:24-6.
24. Forsey T, Darougar S, Dines RJ, Wright DJM, Friedmann PS. Chlamydial genital infection in Addis Ababa, Ethiopia. $\mathrm{Br} J$ Vener Dis 1982;58:370-3.

25. Darougar S, Forsey T, Osoba AO, Dines RJ, Adelusi B, Coker GO. Chlamydial genital infection in Ibadan, Nigeria: a seroepidemiological survey. Br J Vener Dis 1982; 58:366-9.

26. Heyman DL. Etudes sur la gonococcie realisées par des étudiants en médecine au Cameroon. In: Rapport final, 13th Conference Technique, Yaoundé. OCEAC. 1980:661.

27. Sowa S, Sowa J, Collier LH. Investigation of neonatal conjunctivitis in The Gambia. Lancet 1966; ii: 243-7.

28. Sowa S, Sowa J, Collier LH, Blyth W. Trachoma and allied infections in a Gambian village. MRC Special Report Series 1965; No 308.

29. Mabey DCW, Whittle HC. Genital and neonatal chlamydial infections in a trachoma endemic area. Lancet 1982; ii:300-1.

30. Méheus A, Delgadillo R, Widy-Wirski R, Piot P. Chlamydial ophthalmia neonatorum in Central Africa. Lancet 1982; ii:882.

31. Weström L, Bengtsson LP, Mărdh P-A. Incidence, trends, and risks of ectopic pregnancy in a population of women. $B r$ Med J 1981;282: 15-8.

32. Muir DG, Belsey MA. Pelvic inflammatory disease and its consequences in the developing world. Am J Obstet Gynecol 1980; 138: $913-28$.

33. Grech ES, Everett JV, Mukasa F. Epidemiological aspects of acute pelvic inflammatory disease in Uganda. Trop Doct 1973; 3:123-217.

34. Carty MJ, Nzioki JM, Verhagen AR. The role of the gonococcus in acute pelvic inflammatory disease in Nairobi. East Afr Med J 1972; 49: 376-9.

35. Ratnam AV, Din SN, Chatterjee TK. Gonococcal infection in women with pelvic inflammatory disease in Lusaka, Zambia. Am J Obstet Gynecol 1980; 138:965-8.

36. Mårdh P-A. An overview of infectious agents of salpingitis, their biology, and recent advances in methods of detection. Am J Obstet Gynecol 1980;138:933-51.

37. Westrom $\mathrm{L}$. The effect of pelvic inflammatory disease on fertility. Am J Obstet Gynecol 1975; 121:707-13.

38. Arya OP, Taber SR, Nsanze H. Gonorrhoea and female infertility in rural Uganda. Am J Obstet Gynecol 1980; 138: 929-32.

39. Armagnac C, Retel-Laurentin A. Relations between fertility, birth intervals, foetal mortality and maternal health in Upper Volta. Population Studies 1981;35:217-34.

40. Griffith HB. Gonorrhoea and fertility in Uganda. Eugenics Review 1963; 55: 103-8.

41. Billewicz WZ, McGregor IA. The demography of two West African (Gambian) villages, 1951-1975. J Biosoc Sci 1981; 13: 219-40.

42. Rampen $\mathrm{F}$. Venereal syphilis in tropical Africa. $\mathrm{Br} J$ Vener Dis 1978;54:364-8

43. Idsoe $\mathrm{O}$, Kiraly $\mathrm{K}$, Causse G. Venereal disease and treponematoses - the epidemiological situation and WHO's control programme. WHO Chron 1973;27:410-7.

44. Dogliotti M. The incidence of syphilis in the Bantu: survey of 587 cases from Baragwanath hospital. S Afr Med J 1971;45: 8-10.

45. McFadzean JA, McCourt JF, Wilkison AE. Treponematoses in Gambia, West Africa. Trans R Soc Trop Med Hyg 1956;51: 169-81.

46. Nsanze $\mathbf{H}$, Fast MV, D'Costa LJ, Tukei P, Curran J, Ronald A. Genital ulcers in Kenya: clinical and laboratory study. $B r J$ Vener Dis 1981;57:378-81.

47. Méheus A, van Dyck E, Ursi JP, Ballard RC, Piot P. Etiology of genital ulcerations in Swaziland. Sex Transm Dis 1983; 10: 33-5.

48. Sogbetun AO, Montefiore D, Anong CN. Herpes virus hominis antibodies among children and young adults in Ibadan. Br J Vener Dis 1976; 55:44-7. 